\title{
Mechanism of Development of Human Capital Within Human Resources Management of Modern Organization
}

\author{
E.Y. Cherkesova1 \\ S.S. Belikova ${ }^{2}$ \\ E.M. Popova ${ }^{3}$ \\ A.A. Sukhova ${ }^{3}$ \\ N.E. Demidova ${ }^{3}$ \\ ${ }^{1}$ Doctor of Economics, Head of the Department of Human Resources Management, Innovation and Quality, Shakhty Institute \\ (branch) of South-Russian State Polytechnic University (Novocherkassk Polytechnic Institute) named after \\ M.I. Platov, 1 Lenin Sq Shakhty, 346500, Russian Federation \\ 2 Ph.D. in Sociology, Associate Professor of the Department of Human Resources Management, Innovation and Quality, Shakhty \\ Institute (branch) of South-Russian State Polytechnic University (Novocherkassk Polytechnic Institute) named after \\ M.I. Platov, 1 Lenin Sq., Shakhty, 346500, Russian Federation \\ ${ }^{3}$ Ph.D. in Economics, Associate Professor of the Department of Human Resources Management, Innovation and Quality, Shakhty \\ Institute (branch) of South-Russian State Polytechnic University (Novocherkassk Polytechnic Institute) named after \\ M.I. Platov, 1 Lenin Sq., Shakhty, 346500, Russian Federation
}

\section{Doi:10.5901/mjss.2015.v6n5s2p399}

\section{Abstract}

The purpose of the research is the analysis of global practice of development of human capital within human resources management of modern organization and creation of mechanism for development of human capital within human resources management of modern organization. Empirical base of the research consists of the results of comparative international study of practice of human resources management CRANET (Cranfield Network on Comparative Human Resource Management), held by Cranfield School of Management (Great Britain). The authors also use the methodology of evaluation of qualitative index of social investments. As a result of analysis of involvement of organizations into the development of human capital within management of human resources and social responsibility of business in developed and developing countries, the authors come to the conclusion that developed countries pay significant attention to social responsibility and development of human capital, while less than $30 \%$ of business in developing countries pay attention to this issue. Therefore, there is a necessity for creation of the mechanism of development of human capital within human resources management of modern organization, which could be successfully used in developing countries. In order to solve this problem, the authors create the mechanism for development of human capital within human resources management of modern organization, which supposes substantiation of necessity of transition to a new humanist-oriented approach to human resources management and contains recommendations as to implementation of this approach in modern organization. Implementation of this mechanism will allow creating conditions for development of human capital in modern organizations of developing countries and increasing their social responsibility.

Keywords: human capital, human resources management, modern organization, social responsibility of business.

\section{Introduction}

Over the recent years, the topic of social responsibility of business had growing attention from business, authorities, and society. As a result of increase of competition, globalization of financial, labor, and product flows, increase of influence of large transnational companies, transition to innovational economy, and aggravation of ecological and social problems, there is a reconsideration of the role of business in social environment. Instead of traditional understanding of business as activity aimed at receiving profit from production and realization of goods and services and distribution of profit between the members, business is introduced as a source of growth of social well-being which is achieved by manufacture and realization of goods and services.

At the same time, there is a substantial imbalance in development of human capital and social responsibility of business in developed and developing countries of the world. In most developing countries, there are not clear and 
understandable criteria of evaluation of corporate social responsibility and ideas of ethical principles of modern business and economic profit of socially responsible behavior. Low level of corporate management and insufficient reasonability of social expenditures in companies provide negative influence on the formation of socially responsible behavior and facilitates the emergence of larger problems of systemic character on the national and regional level. This determined the topicality of development of viable mechanism of development of human capital within human resources management of modern organization.

The purpose of the article is to analyze the global practice of development of human capital within HR management in modern organization and development of the mechanism of development of human capital within HR management of modern organization. Achievement of this goal supposes solution of the following tasks:

- conducting complex analysis of countries rankings as to involvement of organizations into development of human capital within HR management;

- developing mechanism of development of human capital within HR management of modern organization;

- determining the principles of work of this mechanism and preparing recommendations for its practical implementation by modern organizations.

\section{Methods}

Theoretical basis of this article is comprised by works of modern authors on the issue of research and development of human capital and its role in functioning of modern organizations, among which it is possible to distinguish (Acemoglu et al., 2014), (Berge et al., 2015), (Ciobotaru \&Anghelută, 2014), (Lauder, 2015), (Li et al., 2015), (Manafi \& Subramaniam, 2015), (Perna et al., 2014), etc.

Analysis of wide circle of publications, devoted to building and characterizing national models of human resources management, shows that most of them are founded on single empirical base - the results of comparative international research of practices of human resources management CRANET (Cranfield Network on Comparative Human Resource Management), held by Cranfield School of Management (Great Britain). This research is held annually in the form of survey of HR managers of more than 10,000 companies and organizations from more than 30 countries of the world.

This methodology was chosen under the influence of the three key aspects. Firstly, CRANET is considered to be the fullest and the most representative independent review of practices and technologies of management of human resources in the world. Secondly, the main attention in this research is paid not to opinions on some or other issues and not to verification of "extravagant" hypothesis, but to thorough collection of data as to main functions of work with personnel, which, as a rule, remains beyond the scope of official statistics.

The CRANET research's purpose is full and precise description of practices of human resources management and their further inter-country comparison. The research is conducted with the help of the methods of standardized questionnaire survey of HR managers or heads of HR departments of companies and organizations. The questionnaire consists of six parts: 1) work in the sphere of management of organization's human resources; 2) practice of staff recruitment; 3) development of employees; 4) compensations and subsidies; 5) labor relations and communications; 6) information about organization.

The CRANET report for 2014 provides rankings of countries as to organizations' involvement into the development of human capital within human resources management (Fig. 1).

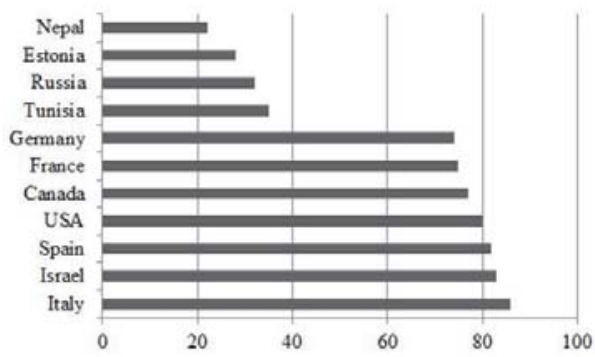

Figure 1. Rankings of countries according to organizations' involvement in development of human capital within human resources management in 2014. (CRANET Survey, 2015) 
As is seen from Fig. 1, organizations' involvement in development of human capital within human resources management is much higher in developed countries. Thus, in Italy, the share of organizations, involved in development of human capital within human resources management was $86 \%$ in 2014, in Israel - 83\%, in Spain - 82\%, and in the USA - 80\%.

At the same time, the share of organizations involved in development of human capital within human resources management was 4 times smaller in developing countries in 2014. Thus, the share of such organizations in Tunisia constituted 35\%, in Russia - 32\%, in Estonia - 28\%, in Nepal - 22\%. This shows the necessity for creating mechanism of development of human capital within human resources management in modern organizations in developing countries.

Development of human capital within human resources management in modern organization determines social responsibility of business. That's why for the analysis of practice of development of human capital within human resources management of modern organization, this research uses the methodology of evaluation of qualitative index of social investments. Qualitative index of social investments ought to evaluate the level of complexity and comprehensiveness of such phenomenon as corporate social responsibility. The idea of this index consists in the accounting of the fact of presence (or absence) of positive parameters in company-respondent. As a result of the study of global practice of social responsibility of business in 2014, the following data was obtained (Fig. 2).

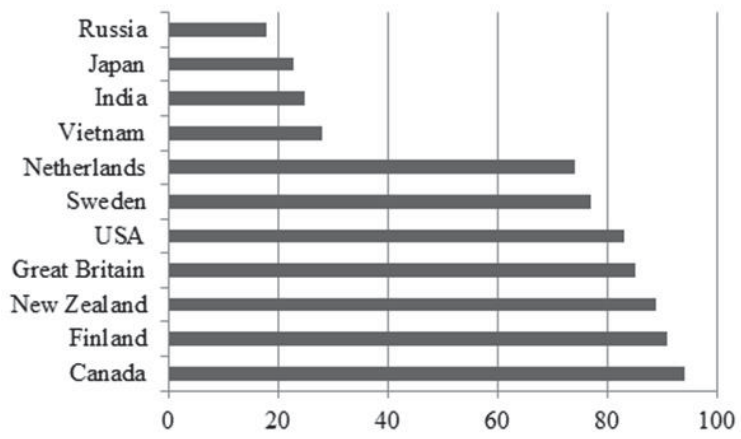

Figure 2. Rankings of countries according to share of socially responsible business in the entrepreneurship structure in 2014. (The JSE Socially Responsible Investment (SRI) Index, 2014)

As is seen from Fig. 2, developed countries are leaders of rankings of social responsibility of business. Thus, in Canada, the level of socially responsible business is $94 \%$, in Finland - 91\%, in New Zealand - 89\%, in Great Britain - 85\%. At that, the share of socially responsible business in developing countries is 5 times smaller. Thus, in Vietnam it constitutes $28 \%$, in India - 25\%, in Japan - 23\%, and in Russia - 18\%.

As a result of analysis of organizations' involvement in development of human capital within human resources management and social responsibility of business in view of developed and developing countries, it is possible to conclude that developed countries pay substantial attention to social responsibility and development of human capital, while less than $30 \%$ of business in developing countries pay attention to this issue. Therefore, there is a necessity for creation of mechanism of development of human capital within human resources management of modern organization, which could be successfully applied in developing countries.

\section{Results}

The mechanism of development of human capital within human resources management of modern organization, offered in this research, is based on the humanistic approach to human resources management. It is oriented not at abstract person but at unique personality. This approach supposes that employees are integrated in the existing system of values, while management is "human resources management" (Popkova and Tinyakova, 2013b).

The offered mechanism is founded on the following principles: stimulation of creative activities, creative atmosphere which activates strong qualities of performers; complex organization of interconnection of performers of all levels - from work place and group to company on the whole; support for comfort of psychological climate; development of formal and informal communications; use of group forms of labor organizations; expansion of replaceability and delegation of rights, employees' participating in decision making; creation of flexible system of selection and 
implementation of new ideas; support for employees' strive for general and professional training within company and outside it; stimulating exchange of opinions and of discussions; providing innovators with material resources; providing them with business information; stimulating susceptibility for changes in organization.

Modern system of motivation of creative activity should be aimed not at material interests of human but at his spiritual origin (Acemoglu et al., 2014). In the process of evolution of managerial concept, attitude towards person in organizations changes drastically. Employee becomes a main subject of organization. The system of stimulation reorients at mobilization of reserves of personality of each employee. It is based on employee's interest in the growth of individual results, manifestation of creative potential, and self-development. Creative activity of personnel becomes a more significant resource and requires activization of all factors which stipulate its development.

Manifestation of creative activity requires the style of management which can stimulate creative ideas and suppress them (Cherkesova et al., 2014c). Employees' initiatives are obstructed by authoritarian style of management which puts strict limits for creativity. Most probably, such style of management would allow realizing only the manager's ideas, while employees would perform only supplementary role. Surely, with strict style of management, employees would think more of work, but that would not lead to desired enthusiasm and internal activity (Berge et al., 2015).

Passive style of management, at first sight, is more appropriate for creative activity of personnel; however, despite the fact that it does not support various regulations, it does not have strict control for personnel's activity, i.e., it provides freedom of actions, which, unfortunately, might lead to problems of cooperation within personnel. With this style of management, any creative initiative might face problems with implementation, as the probability of lack of resources and organizational provision is very high (Ciobotaru and Anghelută, 2014).

Full development of creative activity of personnel requires democratic style of management. The role of positive sides belongs to: division of responsibility, high level of freedom, cooperation of actions and efforts, and easy process of control for performance (Cherkesova et al., 2014b). This style of management could be motivating and inspiring factor for organization employees - if it possesses certain features: creative atmosphere, support for innovational projects and processes, constant professional education and training aimed at personal development of human, openness for new knowledge, and trust relationship at various levels (Popkova and Tinyakova, 2013a).

Any ideas require organizational support - i.e., it is important that they would not remain only in minds of employees or as formality on paper. Availability of feedback is a very important aspect. In order to form creative environment, it is necessary to eliminate bureaucracy (Perna et al., 2014). Not all creative ideas could be in demand and realistic, but every creative initiative should be noticed.

Depending on possibilities of organization, it is possible to realize the following variants: creating structure and appointing manager who would process all creative initiatives. It there is no such possibility, the manager himself could receive the offers of this kind. However, manager could make a mistake of appointing employee to be responsible for the project if the employee showed creative initiative but didn't receive financial and organizational support. In this case, there could form an opinion that "initiative is punished". A mandatory condition of creative activity of personnel is emotional and psychological readiness of employees to realize their creative capabilities (Lauder, 2015).

An absolute advantage belongs to companies which were able to attract talented specialists and employees with creative thinking. Success in modern economy is impossible without "aiming at talents" - strong conviction that presence of employees with huge talent at all levels of corporate ladder helps overtaking the rivals (Cherkesova et al., 2014a). The most successful companies are led by managers which are obsessed with the search for talents. They constantly hire new employees, trying to find and attract more and more valuable people. They distinguish the most "prominent" employees, encouraging them with high wages and promoting them at higher positions.

Creative activity of personnel should be viewed not individually but in totality with other members of creative process. Modern organizations should not just create but implement, coordinate, and bring together the efforts of many various people. Therefore, an important role belongs not only to provision of necessary conditions for implementation of creative potential of certain employees but to creation of team-oriented staff, the efforts of which are aimed at achievement of the set goal (Sverdlova, 2014).

Spirit of joint creation and creative atmosphere are a powerful stimulation of creativity, forming permanent state of creative activity in labor collective. Under these conditions, even the events which are not directly connected to organization's activity (competitions, joints projects, etc.), eventually allow using innovational potential of employees to the favor of a company.

Transformation of intellect and creative potential of human into leading factor of economic growth and main competitive advantage of organizations causes the necessity for search for real methods for employees' maximal using of physical, intellectual, and creative capabilities. This direction should pierce the whole system of human resources management of organization and be reflected in each of its elements (Cherkesov, 2012). 
Stimulation of creative activity of personnel requires complex system of measures which includes (Li et al., 2015):

- planning development of creative activity of personnel, taking into account perspectives of enterprises and professional growth of staff;

- forming perspective requirements to personnel which suppose growth of the level of knowledge and professional skills;

- creating conditions for development of creative activity (organizational, technical, economic, social, and psychological);

- evaluation and analysis of efficiency of work and creative activity of employees with decisions, based on that.

Domination of creative labor supposes new system of scores and strengthening of the role of motivation; it requires new approaches to stimulation of creative activity of personnel. Size of wages is still a very significant stimulus. However, it is not sufficient for inspiration for creation.

An important role belongs to the usage of various forms of acknowledgement of results of creativity, enthusiasm, and initiative (Manafi and Subramaniam, (2015). This included various contests, awarding honorary ranks and titles, publication of individual and collective results of creative work in company newspapers and bulletins, and awarding prizes and special rewards.

As a tool for motivation and stimulation of personnel, the system of grading could be used - it would help to build the positions hierarchically, shoe the value of each of them for organization, and would help to create a system for labor payment depending on work performed by personnel (Cherkesova et al., 2013a). Grading consists in objective evaluation of labor of personnel and search for talented people with creative ideas. This "talents management" allows noticing and keeping important employees at their positions and motivating them fro increase of the results of their work (Ugheoke, et al., 2015).

Successful development of creative activity should be founded on accumulated practical experience of stimulation of personnel and studies of theorists of HR management (Cherkesova et al., 2013b).

It is difficult to unambiguously evaluate the results of creative activities, but formation of creative atmosphere and stimulation of creative initiative, effectively built in the system of HR management, eventually lead to growth of innovational ideas, rationalization proposals, and suggestions which increase the qualitative level and competitiveness of organization (Popkova et al., 2013).

This requires wide use of new methodologies of stimulation and development of creative activity of employees in HR management, integration of scientific approaches into management system, and taking into account value and uniqueness of such resources as intellectual and creative potential of person (Cherkesova et al., 2013c).

Complex use of totality of methods of stimulation allows covering the whole multiplicity of manifestations of creative potential of personality, taking into account many-sided motives and needs of modern employee, and supporting his selfdevelopment and creative realization. Such worker is in high demand in modern economy which is based on knowledge, intellect, and creative approach to labor.

\section{Conclusion}

Thus, it is possible to conclude that the created mechanism of development of human potential within human resources management of modern organization is oriented at developing countries and supposes substantiation of transition to a new humanist-oriented approach to management of human resources and contains recommendations as to implementation of this approach in modern organization.

Implementing this mechanism would allow creating conditions for development of human capital in modern organizations of developing countries and increasing their social responsibility. Practical implementation of developed mechanism and analysis of national peculiarities of its usage, as well as development of specific recommendations as to universalization of the mechanism, are the perspective direction for further research.

\section{References}

Acemoglu, D., Gallego, F.A., Robinson, J.A. (2014). Institutions, human capital, and development. Annual Review of Economics, 6(1), 875-912.

Berge, L.I.O., Bjorvatn, K., Tungodden, B. (2015). Human and financial capital for microenterprise development, Evidence from a field and lab experiment. Management Science, 61(4), 707-722.

CRANET Survey on Comparative Human Resource Management. International Executive Report 2014 (2015). CRANET. 
Ciobotaru, A.V., Anghelută, P.S. (2014). Human capital in context of sustainable development. Quality - Access to Success,15 (1), 417 421

Lauder, H. (2015) Human capital theory, the power of transnational companies and a political response in relation to education and economic development. Compare, 45(3), 490-493.

Li, Y., Zhang, G., Yang, X., Li, J. (2015). The influence of collectivist human resource management practices on team-level identification. Source of the International Journal of Human Resource Management, 26(14), 1791-1806

Manafi, M., Subramaniam, I.D. (2015). Balancing performance by human resource management practices. Source of the Asian Social Science, 11(10), 386-400

Perna, L.W., Orosz, K., Gopaul, B., (...),Ashirbekov, A., Kishkentayeva, M. (2014). Promoting Human Capital Development, A Typology of International Scholarship Programs in Higher Education. Educational Researcher, 43(2), 63-73

Popkova, E.G. \& Tinyakova V.I. (2013a). New Quality of Economic Growth at the Present Stage of Development of the World Economy. World Applied Sciences Journal, 5, 617-622.

Popkova, E.G. \& Tinyakova, V.I. (2013b). Drivers and Contradictions of Formation of New Quality of Economic Growth. Middle-East Journal of Scientific Research, 11, 1635-1640.

Popkova, E.G., S.S. Morkovina, E.V. Patsyuk, E.A. Panyavina \& Popov, E.V. (2013). Marketing Strategy of Overcoming of Lag in Development of Economic Systems. World Applied Sciences Journal, 5, 591-595.

Sverdlova, Y. (2014). Influence of human capital development on competitiveness of the EU economy. Economic Annals-XXI, 7(8), 1215.

The JSE Socially Responsible Investment (SRI) Index promotes sustainable and transparent business practicesю (2014). JSE SRI Annual Review Results.

Ugheoke, S.O., Isa, M.F.M., Mohd Noor, W.S.W. (2015). Antecedents of strategic human resource management practices on intangible firm performance, Analytical investigation of SMEs. Asian Social Science, 11(13), 33-44.

Cherkesova E.Y. (2012). Human factor in knowledge economics. Bulletin of South Russia State Technical University (Novocherkassk Polytechnic Institute). Series: Socio-economic sciences, 4, 124-128.

Cherkesova E.Y., Topchienko L.N. (2007). Analysis of dynamics of unemployment in coal region of Russian Donbass. Mountain informational \& analytical bulleting (scientific \& technical journal), 5, 215-219.

Cherkesova E.Y., Demidova N.Y., Grevtseva Y.A., Suhova A.A. (2013a). Reasoning of Basic Salaries as Factor of Growth of Labour Quality of Budgetary Organizations' Staff. World Applied Sciences Journal. (Education, Law, Economics, Language and Communication), 27(13A), 07-11.

Cherkesova E.Y., Demidova N.Y., Suhova A.A. (2013b). Accounting the Intellectual and Labour Personnel's Efforts as an Innovation Tool of the Remuneration System in the Public Sector. World Applied Sciences Journal. (Education, Law, Economics, Language and Communication), 27(13A) 519-524.

Cherkesova E.Y., Dovlatyan G.P., Smolyakova E.A. (2014a). Modern problems of managing labor motivation of municipal workers by the example of employees of City Duma of Shakhty, Rostov Oblast. International scientific journal "Modern fundamental and applied research", 13(14), 95-97.

Cherkesova E.Y., Dovlatyan G.P., Makhkamova I.S. (2014b). Work force and its mobility in the labor market. International scientific journal "Modern fundamental and applied research", 2(13), 145-147.

Cherkesova E.Y., Demidova N.E., Skoblikov V.V. (2014c). Methodology of material stimulation of innovative activities in coal-mining production. Bulletin of South Russia State Technical University (Novocherkassk Polytechnic Institute). Series: Socio-economic sciences, 3, 11-19. 